\title{
Pengaruh Bentuk Scrotal Bipartition terhadap Kadar Follicle Stimulating Hormone (FSH) dan Testosteron Kambing Kejobong
}

\author{
Yuni Widiarti, Enny Tantini Setiatin, dan Edy Kurnianto \\ Fakultas Peternakan dan Pertanian, Universitas Diponegoro, Semarang, \\ Indonesia \\ E-mail: yuniwidiarti94@gmail.com
}

\begin{abstract}
ABSTRAK
Tujuan penelitian ini adalah untuk mengetahui pengaruh bentuk skrotum terhadap kadar Follicle Stimulating Hormone (FSH) dan testosteron pada kambing Kejobong. Materi yang digunakan dalam penelitian ini adalah kambing Kejobong jantan sebanyak 18 ekor (11 ekor bentuk skrotum A dan 7 ekor bentuk skrotum B), alat yang digunakan adalah pita ukur, jangka sorong, spuit, tabung vacutainer no additive, tabung Effendorf, kulkas, dan cool box. Metode yang dilakukan dalam penelitian adalah observasional, yaitu mengamati secara langsung bentuk skrotum ternak, mengukur panjang, lebar dan lingkar skrotum, mengukur lebar dan lingkar testis, dan mengambil sampel darah pada vena jugularis. Sampel darah dianalisis untuk diukur kadar hormon menggunakan metode Enzym Immunoassay (EIA), EIA Test Kit dengan Catalog Number : 4S00055 digunakan untuk analisa FSH dan EIA Test Kit dengan Catalog Number : 4S00072 dari General Biologicals Corp (GBC) digunakan untuk analisa testosteron. Parameter yang diukur yaitu bentuk scrotal bipartition, kadar follicle stimulating hormone dan testosteron. Perbedaaan respon dari bentuk skrotum terhadap kadar hormon FSH dan testosteron dianalisis menggunakan uji-t pada taraf 5\%. Hasil penelitian menunjukkan bahwa ada dua bentuk skrotum pada kambing Kejobong, yaitu bentuk skrotum A (no bipartition) dan bentuk skrotum B (bipartition $<50 \%$ ). Pada bentuk skrotum A, nilai rata-rata lingkar skrotum bagian kanan adalah $14,1 \pm 2,8 \mathrm{~cm}$ dan bagian kiri 13,9 $\pm 2,3 \mathrm{~cm}$. Nilai rata-rata lebar testis bagian kanan adalah 3,5 $\pm 0,3 \mathrm{~cm}$ dan bagian kiri memiliki lebar 3,5 $\pm 0,4 \mathrm{~cm}$. Pada bentuk skrotum B, nilai rata-rata lingkar skrotum bagian kanan adalah 13,3 $\pm 1,2 \mathrm{~cm}$ dan bagian kiri 13,7 $\pm 1,9 \mathrm{~cm}$. Nilai rata-rata lebar testis kanan adalah 3,2 $\pm 0,3 \mathrm{~cm}$ dan bagian kiri 3,4 $\pm 0,2 \mathrm{~cm}$. Nilai kadar FSH pada skrotum A yaitu 1,8113 $\pm 0,4115$ $\mathrm{mIU} / \mathrm{ml}$ dan kadar pada skrotum B yaitu $1,6490 \pm 0,6756 \mathrm{mIU} / \mathrm{ml}$. Kadar testosteron pada skrotum A 0,9841 $\pm 0,6212 \mathrm{ng} / \mathrm{ml}$ dan pada skrotum B yaitu $0,6925 \pm 1,5537 \mathrm{ng} / \mathrm{ml}$. Hasil uji-t menunjukkan bahwa bentuk skrotum tidak berpengaruh $(\mathrm{P}>5 \%)$ terhadap kadar FSH maupun testosteron.Simpulan dari hasil penelitian ini adalah bentuk skrotum pada kambing Kejobong tidak mempengaruhi kadar FSH maupun testosteron.

Kata kunci: kambing Kejobong, bentuk skrotum, follicle stimulating hormone, testosteron.
\end{abstract}

\begin{abstract}
The objective of study was to determine the effect of scrotal bipartition shape on follicle stimulating hormone (FSH) and testosterone level in Kejobong goat. The material used in this study is 18 male Kejobon goats (11 goats with type scrotum A and 7 goats with type scrotal B), the tools used is measurment tool, calipers, spuit, vacutainer tube no additive, effendorf tube, refrigerator, and coolbox. The method carried out in the study was measurement the shape of the scrotum directly, measure the length, width and circumference of the scrotum, measure the width and circumference of the testicles, and take blood samples in the jugular vein. Blood samples were analyzed to measure hormone levels using the Enzym Immunoassay method (EIA), EIA Test Kit with Catalog Number : 4S00055 to FSH analys and EIA Test Kit with Catalog Number : 4 S00072 from General Biologicals Corp (GBC) to testosterone analys. The parameters measured were scrotal bipartition, follicle stimulating hormone and testosterone level. T-test was used for testing the difference response from scrotal bipartition shape in FSH and testosteron level at the level of 5\%. The results showed that there were two scrotal shape in the Kejobong goat, namely scrotal shape A (no bipartition) and scrotal shape B (bipartition $<50 \%$ ). In scrotum shape A, the averge of the right scrotal circumference was $14.1 \pm 2.8$ $\mathrm{cm}$ and the left part $13.9 \pm 2.3 \mathrm{~cm}$.
\end{abstract}


The average value of the width of the right testicle is $3.5 \pm 0.3 \mathrm{~cm}$ and the left side has a width of $3.5 \pm$ $0.4 \mathrm{~cm}$. In scrotum shape B, the average of the right scrotal circumference was $13.3 \pm 1.2 \mathrm{~cm}$ and the left part was $13.7 \pm 1.9 \mathrm{~cm}$. The average value of the width of the right testis was $3.2 \pm 0.3 \mathrm{~cm}$ and the left part was 3.4 $\pm 0.2 \mathrm{~cm}$. The value of FSH levels in scrotal A is $1.8113 \pm 0.4115 \mathrm{mIU} / \mathrm{ml}$ and the level in scrotal B is 1.6490 $\pm 0.6756 \mathrm{mIU} / \mathrm{ml}$. Testosterone levels in scrotal A $0.9841 \pm 0.6212 \mathrm{ng} / \mathrm{ml}$ and scrotal B at $0.6925 \pm 1.5537$ $\mathrm{ng} / \mathrm{ml}$. The results of the $t$-test showed that the scrotal shape had no effect $(P>5 \%)$ on the levels of FSH or testosterone.

Key word : Kejobong goat, scrotum shape, follicle stimulating hormone, testosteron.

\section{PENDAHULUAN}

Masyarakat Indonesia mengenal cara pemilihan ternak sebagai pejantan unggul berdasarkan pada bentuk tubuh yang ideal, mampu berdiri kokoh, dan memiliki keinginan kawin yang tinggi. Pemilihan pejantan menjadi penentu dalam meningkatkan bibit atau keturunan selanjutnya (Syamyono et al., 2015). Selain itu, pemilihan ternak produktif dilihat juga berdasarkan kesehatan, umur, lingkungan, ukuran testis dan ukuran skrotum (Kostaman et al., 2004). Produktivitas ternak juga berkaitan dengan kadar hormon yang diproduksi oleh tubuh ternak, karena hormon akan berpengaruh pada sistem spermatogenesis. Hormon yang berperan dalam proses spermatogenesis adalah Follicle Stimulating Hormone (FSH), Luteinizing Hormone (LH) dan testosteron. FSH mempunyai peran dalam proses pematangan sperma (Purwoistri, 2010), sementara testosteron berperan dalam peningkatan libido ternak (Rachmawati et al., 2014).

Bentuk dan ukuran skrotum jika dilihat secara langsung memiliki pengaruh dengan ukuran testis. Hal ini dikarenakan testis sendiri merupakan organ primer pada ternak jantan yang terbungkus didalam skrotum (Hendri et al., 2017). Ukuran testis memiliki hubungan erat terhadap proses spermatogenesis, kualitas semen, kemampuannya dalam mengawini betina dan tingginya fertilitas (Kostaman et al., 2004). Pada ternak domba terdapat dua bentuk skrotum yaitu bentuk skrotum with bipartition dan without bipartition. Domba dengan bentuk skrotum yang memiliki partisi (with bipartition), lebih memiliki indikasi indeks reproduksi yang lebih baik dibandingkan dengan ternak yang memiliki bentuk skrotum without bipartition. Sel meiotik, spermatogenetik, dan sel sertoli pada domba dengan bentuk skrotum with bipartition memiliki efisiensi lebih tinggi dibandingkan domba bentuk skrotum without bipartition (Rodrigues et al., 2016).

Adanya informasi penelitian bentuk skrotum pada domba tersebut, maka penelitian ini dilakukan untuk mengetahui bentuk skrotum pada kambing Kejobong. Kambing Kejobong merupakan ternak yang tersebar di Kabupaten Purbalingga, Jawa
Tengah dengan jumlah populasi terbanyak berada di Kecamatan Kejobong, Bukateja, Kaligondang, dan Pengadegan (Sodiq, 2009). Karena penelitian yang serupa belum pernah dilakukan di Indonesia, sehingga untuk memperoleh data dan menambah informasi, penelitian ini dilakukan

untuk mengkaji bentuk skrotum kambing Kejobong dan pengaruhnya terhadap kadar hormon FSH dan testosteron.

Penelitian ini bertujuan untuk mengetahui pengaruh bentuk skrotum terhadap kadar Follicle Stimulating Hormone (FSH) dan testosteron pada kambing Kejobong. Manfaat yang diperoleh dari penelitian ini adalah mengetahui bentuk skrotum dan memberikan informasi kepada masyarakat tentang pengaruhnya terhadap kadar FSH dan testosteron, karena kadar FSH yang rendah akan berpengaruh pada rendahnya rangsangan untuk sel sertoli dalam proses spermatogenesis. Kadar testosteron yang tinggi akan berpengaruh pada tingkat libido ternak.

Hipotesis penelitian ini adalah ada pengaruh bentuk skrotum terhadap kadar FSH dan testosteron pada kambing Kejobong.

\section{MATERI DAN METODE}

\section{Materi}

Materi yang digunakan dalam penelitian ini adalah kambing Kejobong jantan 11 ekor dengan bentuk skrotum A (no bipartition) dan 7 ekor dengan bentuk skrotum B (bipartition $<50 \%$ ) yang dipelihara oleh Kelompok Tani Ternak di Purbalingga.

Alat yang digunakan yaitu pita ukur untuk mengukur lingkar skrotum ternak, jangka sorong untuk mengukur panjang dan lebar testis, spuit untuk menampung sampel darah, tabung vacutainer no additive (tabung dengan tutup berwarna merah) sebagai tempat sampel darah, tabung Effendorf sebagai tempat serum, kulkas untuk menyimpan serum, cool box sebagai tempat menyimpan sampel saat perjalanan atau transportasi, EIA Test Kit dengan Catalog Number : 4S00055 digunakan untuk analisa FSH dan EIA Test Kit dengan Catalog Number : 
4S00072 dari General Biologicals Corp (GBC) digunakan untuk analisa testosteron.

\section{Metode}

Penelitian ini mengunakan metode observasional, yang terdiri dari empat tahapan penelitian yaitu prosedur penelitian, parameter yang diukur, analisis data dan hipotesis penelitian.

\section{Prosedur penelitian}

Proses pengamatan bentuk skrotum. Penelitian ini diawali dengan mengamati bentuk scrotal bipartition kambing Kejobong, kemudian mengukur skrotum dan testis dengan alat ukur dan mencatat semua data yang diperoleh. Metode yang dilakukan pertama kali adalah melihat recording di peternakan dengan tujuan bisa mengetahui umur ternak. Kemudian dilanjutkan dengan mengamati bentuk skrotum pada ternak dan melakukan pengukuran. Pengukuran yang dilakukan pada skrotum, yaitu panjang, lebar dan lingkar skrotum per bagian dengan menggunakan pita ukur sebanyak 3 kali pengukuran. Selain mengamati bentuk skrotum, testis kambing Kejobong juga dilakukan pengukuran sebagai data pendukung penelitian. Pengukuran yang dilakukan yaitu lebar testis per bagian dengan menggunakan jangka sorong sebanyak 3 kali pengukuran.

Pengambilan sampel darah. Prosedur yang dilakukan adalah menyiapkan spuit, kapas yang dibasahi dengan alkohol dan tabung vacutainer no additive, kemudian handling ternak yang akan diambil darahnya. Pengambilan sampel darah dilakukan melalui vena jugularis sebanyak 5-10 ml yang terletak pada bagian leher ternak seperti digambarkan pada Ilustrasi 1 . berikut :

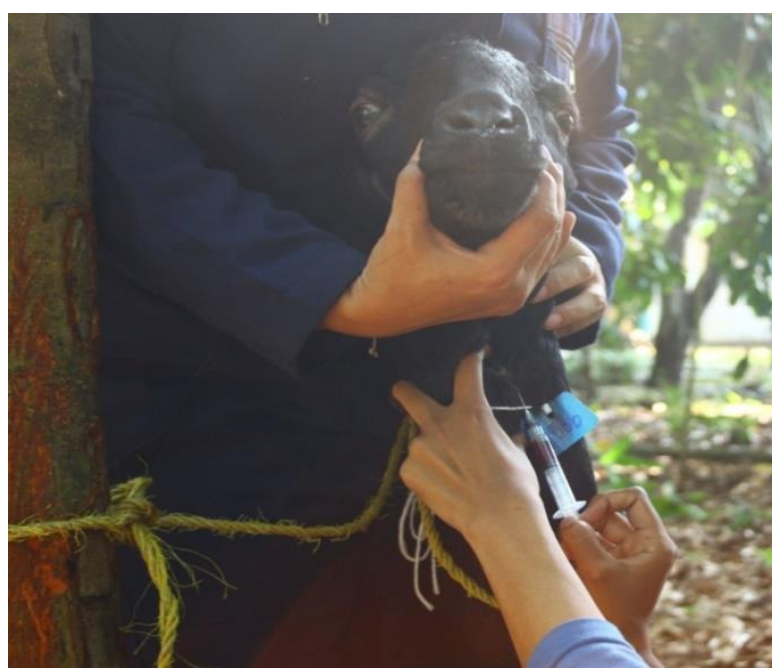

Ilustrasi 1. Pengambilan Sampel Darah pada Vena Jugularis
Sampel darah yang telah dimasukkan kedalam tabung didiamkan, kemudian pisahkan darah dengan serum, lalu serum dipindahkan kedalam tabung Effendorf, kemudian dimasukkan kedalam frezzer untuk disimpan. Darah disimpan sementara hingga penelitian selesai, kemudian analisis darah dilakukan di Laboratorium GAKI, Fakultas Kedokteran, Universitas Diponegoro untuk mengetahui kadar hormon menggunakan metode Enzyme Immunoassay (EIA). Analisa FSH menggunakan EIA Test Kit dengan Catalog Number : 4S00055 dan analisa testosteron menggunakan EIA Test Kit dengan Catalog Number : 4S00072 dari General Biologicals Corp (GBC).

\section{Parameter penelitian}

Parameter dalam penelitian ini adalah bentuk scrotal bipartition, kadar follicle stimulating hormone dan testosteron.

\section{Analisis data}

Data yang telah terkumpul dianalisis menggunakan perhitungan t-test (Shinjo, 1990). Perhitungan t-test ini digunakan untuk mengetahui ada atau tidaknya pengaruh antara bentuk skrotum yang berbeda dengan kadar FSH dan testosteron. Rumus yang digunakan adalah sebagai berikut :

$$
\begin{aligned}
& \mathrm{Se}=\sqrt{\frac{\left[\sum_{\mathrm{i}=1}^{\mathrm{n}} \mathrm{x}_{1 \mathrm{i}} 2-\frac{1}{\mathrm{n} 1}\left(\sum_{\mathrm{i}=1}^{\mathrm{n}} \mathrm{x}_{1 \mathrm{i}}\right)^{2}\right]+\left[\sum_{\mathrm{i}=1}^{\mathrm{n}} \mathrm{x}_{2 \mathrm{i}} 2-\frac{1}{\mathrm{n} 2}\left(\sum_{\mathrm{i}=1}^{\mathrm{n}} \mathrm{x}_{2 \mathrm{i}}\right)^{2}\right]}{\mathrm{n} 1+\mathrm{n} 2-2}\left(\frac{1}{\mathrm{n} 1}+\frac{1}{\mathrm{n} 2}\right)} \\
& \mathrm{t} \text {-test }=\left|\frac{\bar{x}_{i}-\bar{x}_{2}}{\mathrm{Se}}\right|
\end{aligned}
$$

Keterangan :

$\mathrm{x} 1=$ kadar hormon pada bentuk skrotum $\mathrm{A}$

$\mathrm{x} 2=$ kadar hormon pada bentuk skrotum $\mathrm{B}$

n1 = jumlah ternak dengan dengan hormon FSH atau testosteron pada skrotum bentuk A

n2 = jumlah ternak dengan dengan hormon FSH atau testosteron pada skrotum bentuk B

\section{Hipotesis penelitian}

$\mathrm{HO}=$ tidak ada pengaruh antara bentuk skrotum terhadap kadar hormon pada kambing Kejobong

$\mathrm{H} 1$ = ada pengaruh antara bentuk skrotum terhadap kadar hormon pada kambing Kejobong

Jika t hitung $\leq \mathrm{t}$ tabel, maka $\mathrm{H} 0$ diterima

Jika t hitung $\geq \mathrm{t}$ tabel, maka $\mathrm{H} 0$ ditolak, H1 diterima. 


\section{HASIL DAN \\ PEMBAHASAN}

\section{Ukuran Skrotum dan Testis pada Kambing Kejobong}

Berdasarkan penelitian yang telah dilaksanakan diperoleh bentuk skrotum pada pengamatan ada dua bentuk yaitu bentuk A dan bentuk B, sebagaimana digambarkan pada Ilustrasi 2.

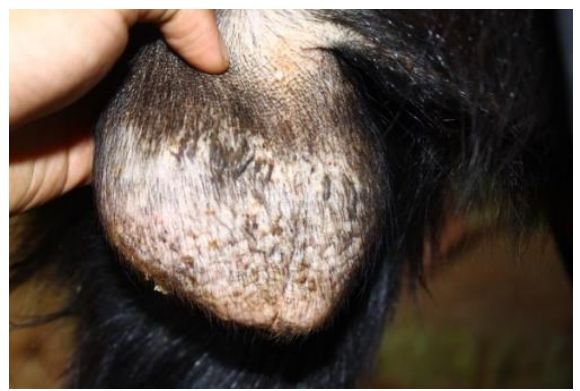

A (no bipartition)

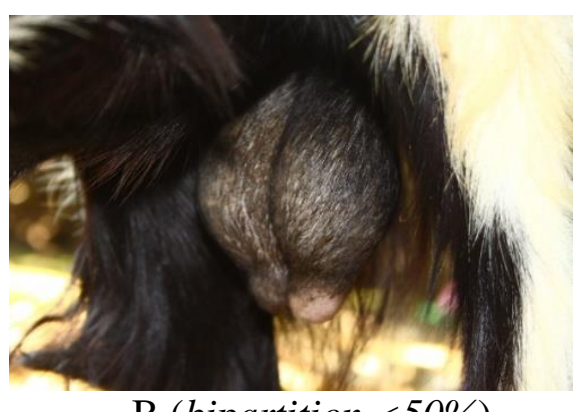

B (bipartition <50\%)
Ilustrasi 2. Bentuk Skrotum Kambing Kejobong

Bentuk skrotum A adalah skrotum dengan bentuk yang tidak tampak jelas ada belahan (no bipartition), sementara bentuk skrotum B adalah skrotum yang terlihat jelas ada belahan (bipartition <50\%). Hasil penelitian ini tidak berbeda dengan penelitian yang diperoleh oleh Rodrigues et al. (2016) yang menyatakan bahwa bentuk skrotum pada domba ada 2 bentuk, yaitu bentuk with bipartition dan without bipartition. Pada penelitian yang dilakukan oleh Almeida et al. (2010) bentuk skrotum pada kambing ada 3 , yaitu simple bipartition, $50 \%$ of bipartite dan $>50 \%$ of bipartite. Almeida et al. (2010) menyatakan bahwa ternak dengan bentuk skrotum yang terbagi (bipartition) memiliki bobot badan lebih tinggi, cacat sperma yang lebih rendah dan memiliki panjang testis yang lebih dibandingkan ternak dengan bentuk skrotum simple bipartition. Hasil pengukuran pada testis dan skrotum kambing Kejobong disajikan pada Tabel 1.

Tabel 1. Ukuran Lebar Testis dan Lingkar Skrotum Kambing Kejobong

\begin{tabular}{lcccc} 
Bentuk & \multicolumn{2}{c}{ Lebar Testis } & \multicolumn{2}{c}{ Lingkar Skrotum } \\
\cline { 2 - 5 } Skrotum & Kanan & Kiri & Kanan & Kiri \\
\cline { 2 - 5 } A & $----------------------------~(c m) ~$ & $14,1 \pm 2,8$ & $13,9 \pm 2,3$ \\
B & $3,5 \pm 0,3$ & $3,5 \pm 0,4$ & $13,3 \pm 1,2$ & $13,7 \pm 1,9$ \\
\hline
\end{tabular}

Hasil penelitian ukuran skrotum dan testis kambing Kejobong (Tabel 1) menunjukkan bahwa bentuk skrotum A dan B memiliki ukuran skrotum yang tidak jauh berbeda. Lingkar skrotum pada kambing Kejobong ini memiliki angka yang berbeda dengan hasil yang diperoleh oleh Hendri et al. (2017) yaitu lingkar skrotum pada kambing Peranakan Ettawa (PE) pada umur 1 - 1,5 adalah $24,1 \pm 1,5$ dan pada umur $2-4$ tahun adalah $26,4 \pm$ $0,9 \mathrm{~cm}$. Menurut Rodrigues et al. (2016) lingkar skrotum pada domba with bipartition adalah 25,33 $\pm 1,21 \mathrm{~cm}$ dan without bipartition adalah $25,16 \pm$ $1,94 \mathrm{~cm}$. Syamyono et al. (2015) menyatakan bahwa lingkar skrotum pada kambing Kejobong muda yaitu 19,1 - 25,0 cm dan kambing Kejobong dewasa $21,1-27,0 \mathrm{~cm}$.

Hasil penelitian menunjukkan bahwa lebar testis pada kambing Kejobong (Tabel 1) pada bentuk skrotum A dan B memiliki ukuran testis yang sama. Angka ini berbeda dengan hasil penelitian yang diperoleh oleh Rodrigues et al. (2016) yang menyatakan bahwa lebar testis kanan pada skrotum domba with bipartition adalah 4,92 \pm $0,19 \mathrm{~cm}$ dan yang kiri adalah 4,92 $\pm 0,26 \mathrm{~cm}$. Lebar testis kanan pada skrotum without bipartition adalah $4,83 \pm 0,17 \mathrm{~cm}$ dan yang kiri adalah $4,83 \pm$ $0,17 \mathrm{~cm}$. Almeida et al. (2010) menyatakan bahwa panjang testis kanan pada kambing dengan bentuk simple scrotum adalah $5,54 \pm 0,10 \mathrm{~cm}$ dan yang kiri 
$5,54 \pm 0,10 \mathrm{~cm}$. Panjang testis kanan pada bentuk $50 \%$ of bipartite adalah $6,29 \pm 0,17 \mathrm{~cm}$ dan yang kiri adalah 6,20 $\pm 0,18 \mathrm{~cm}$. Panjang testis kanan pada bentuk $>50 \%$ of bipartite adalah $6,36 \pm 0,17$ $\mathrm{cm}$ dan yang kiri adalah $6,23 \pm 0,19 \mathrm{~cm}$.

\section{Pengaruh Bentuk Skrotum terhadap Kadar Hormon Kambing Kejobong}

Berdasarkan hasil penelitian yang telah dilakukan, kadar hormon pada kambing Kejobong disajikan pada Tabel 2. Hasil penelitian menunjukkan bahwa kambing Kejobong dengan bentuk skrotum yang berbeda tidak memiliki perbedaaan terhadap kadar hormon yang dihasilkan, baik FSH maupun testosteronnya. FSH dan testosteron merupakan hormon yang akan berperan dalam proses spermatogenesis.

Tabel 2. Kadar Hormon Kambing Kejobong

\begin{tabular}{lcc}
\hline \multirow{2}{*}{ Hormon } & \multicolumn{3}{c}{ Bentuk Skrotum } \\
\cline { 2 - 3 } & A & B \\
\hline FSH $(\mathrm{mIU} / \mathrm{ml})$ & $1,8113 \pm 0,4115$ & $1,6490 \pm 0,6756$ \\
Testosteron $(\mathrm{ng} / \mathrm{ml})$ & $0,9841 \pm 0,6212$ & $0,6925 \pm 1,5537$
\end{tabular}

Partodihardjo (1982) menyatakan bahwa hormon merupakan zat organik yang dihasilkan oleh sekelompok sel-sel tertentu dalam badan dan dirembeskan ke dalam sirkulasi darah dengan jumlah sangat kecil yang dapat merangsang sel-sel tertentu dalam badan untuk berfungsi. Oduwole et al. (2018) menyatakan bahwa sistem reproduksi dikendalikan oleh hormon-hormon fungsional dalam hipotalamus hipofisis gonad. Follicle Stimulating Hormone (FSH), Luteinizing Hormone (LH) dan testosteron berperan dalam proses spermatogenesis. Spermatogenesis sendiri merupakan urutan yang kompleks dan teratur selama spermatogonia diploid berkembang biak dan berdiferensiasi menjadi haploid spermatozoa.

\section{Pengaruh bentuk skrotum terhadap kadar follicle stimulating hormone (FSH) pada kambing Kejobong Berdasarkan penelitian yang telah} dilaksanakan diperoleh hasil bahwa rata-rata kadar FSH kambing Kejobong pada bentuk skrotum A (no bipartition) adalah $1,8113 \pm 0,4115 \mathrm{mIU} / \mathrm{ml}$ dan pada bentuk skrotum B (bipartition <50\%) adalah 1,6490 $\pm 0,6756 \mathrm{mIU} / \mathrm{ml}$ (Tabel 3). Uji-t menunjukkan bahwa tidak ada pengaruh bentuk skrotum A maupun bentuk skrotum B ( $>>5 \%)$ terhadap kadar FSH (Lampiran 5). Hal ini sesuai dengan pendapat Rodrigues et al. (2016) yang menyatakan bahwa bentuk skrotum tidak memiliki pengaruh pada sel sertoli yang dibentuk oleh FSH. Hasbi dan Gustina (2018) menyatakan bahwa Follicle Stimulating Hormone (FSH) memiliki peran dalam mengontrol sel sertoli yang menyebabkan terjadinya peningkatan volume testis.

Pada sistem reproduksi ternak, kadar FSH tersebut akan berperan dalam proses spermatogenesis. Akmal et al. (2015) menyatakan bahwa spermatogenesis pada mamalia merupakan program perkembangan yang kompleks. Proses berlangsungnya terjadi di dalam epithelium seminiferus testis mamalia. Spermatogenesis ini dimulai ketika spermatogonia mengalami poliferasi dan diferensiasi menjadi spermatosit primer, kemudian diikuti dengan meiosis yang menghasilkan round spermatid haploid. Round spermatid haploid kemudian mengalami perubahan morfologi yang dramatis hingga akhirnya menjadi spermatozoa yang matang.

\section{Pengaruh bentuk skrotum terhadap kadar hormon testosteron pada kambing Kejobong}

Berdasarkan penelitian yang telah dilaksanakan diperoleh hasil bahwa rata-rata kadar testosteron kambing Kejobong pada bentuk skrotum A adalah $0,9841 \pm 0,6212 \mathrm{ng} / \mathrm{ml}$ dan pada bentuk skrotum B adalah $0,6925 \pm 1,5537 \mathrm{ng} / \mathrm{ml}$ (Tabel 2). Uji-t menunjukkan tidak ada pengaruh $(\mathrm{P}>5 \%)$ antara bentuk skrotum dengan kadar testosteron. Hal ini sesuai dengan pendapat Hendri et al. (2017) yang menyatakan bahwa kadar hormon pada ternak kambing dipengaruhi oleh ukuran skrotum. Rachmawati et al. (2014) menyatakan bahwa kadar hormon pada ternak jantan sangat erat kaitannya dengan tingkat libido atau aktivitas seksual ternak dan juga menentukan kualitas sperma. Semakin tinggi kadar testosteron yang dimiliki ternak jantan maka semakin tinggi pula tingkat libido dan semakin baik pula kualitas sperma yang dihasilkan.

Testosteron merupakan hormon yang terlibat dalam memberikan stimulus untuk mendorong aktivitas seksual ternak. Kadar hormon testosteron akan mempengaruhi tingkat libido pada kambing jantan. Syamyono et al. (2015) 
menyatakan bahwa testosteron memiliki peran terhadap perkembangan organ kelamin primer, sifat kelamin sekunder dan pembesaran fibril. Selain itu, kadar hormon juga dipengaruhi oleh umur ternak.

\section{KESIMPULAN}

Berdasarkan penelitian yang telah dilakukan diperoleh hasil bahwa bentuk skrotum pada kambing Kejobong tidak mempengaruhi kadar Follicle Stimulating Hormone (FSH) maupun testosteron.

\section{REFERENSI}

Akmal, M., D. Masyitah, Hafizuddin dan Fitriani. 2015. Epididimis dan perannya pada pematangan spermatozoa. Jesbio. 4 (2): 1-9.

Almeida, M.M, A.A.N.M. Junior, C.E. Ambrosio, D.J.A. Menezes, D.A Righi, I.M.R. Nascimento dan M.A.M. Carvalho. 2010. Influence of the scrotum bipartite on the reproductive parameters in goats. Pesq. Vet. Bras. 30 (4): 345-350.

Hasbi, H. dan S. Gustina. 2018. Regulasi androgen dalam spermatogenesis untuk meningkatkan fertilitas ternak jantan. Wartazoa. 28 (2): 13-22.

Hendri, M., G. Riady dan R. Daud. 2017. Hubungan lingkar skrotum dan konsentrasi spermatozoa pada kambing Peranakan Ettawa (PE) jantan. Jimvet. 2 (1): 41-50.

Kostaman, T., M. Martawidjaja, I. Herdiawan dan IK. Sutama. 2004. Hubungan antara lingkar skrotum dengan bobot badan, volume semen, motilitas progresif dan konsentrasi spermatozoa pada kambing jantan muda. Prosiding Seminar Nasional Teknologi Peternakan dan Veteriner Iptek sebagai
Penggerak Pembangunan Sistem dan Usaha Agribisnis Peternakan. Bogor 4-5 Agustus 2004. Pusat Penelitian dan Pengembangan Peternakan. Hal : 385-388.

Oduwole, O.O., H. Peltoketo dan I.T. Huhtaniemi. 2018. Role of follicle stimulating hormon in spermatogenesis. Frontiers in Endocrinology. 9 (763): 1-11.

Partodihardjo, D.S. 1982. Ilmu Reproduksi Ternak. Mutiara, Jakarta.

Purwoistri, R.T. 2010. Pengaruh Ekstrak Biji Pepaya (Carica papaya L.) Terhadap Spermatogenesis dan Tebal Epitel Tubulus Seminiferus Testis Mencit (Mus musculus) Jantan. Fakultas Sains dan Teknologi Universitas Islam Negeri Maulana Malik Ibrahim, Malang (Skripsi).

Rachmawati, L., Ismayana dan P. Astuti. 2014. Korelasi antara hormon testosteron, libido, dan kualitas sperma pada kambing Bligon, Kejobong dan Peranakan Etawah. Buletin Peternakan. 38 (1): 8-15.

Rodrigues, R.T.G.A., J.R.S. Santoso, L.M.S. Azeredo, E.F. Rocha, M.A.M. Carvalho, M.J.I.D. Portal, O.B. Sousa dan D.J.A. Menezes. 2016. Influence of scrotal bipartition on spermatogenesis yield and sertoli sell efficiency in sheep. Pesq. Vet. Bras. 36 (4): 258-262.

Shinjo, A. 1990. First Course in Statistics. University of the Ryukus Nishihara-cho, Okinawa.

Sodiq, A. 2009. Karakteristik sumberdaya kambing lokal khas Kejobong di Kabupaten Purbalingga Provinsi Jawa Tengah. Agripet. 9 (1): 31-37.

Syamyono, O., D. Samsudewa dan E.T. Setiatin. 2015. Karakteristik semen dan kadar terstosteron berdasarkan ukuran lingkar skrotum kambing Kejobong muda dan dewasa. Jurnal Veteriner. 16 (2): 256-264. 